\title{
Taxonomy and phylogeny of a new Central American beetle genus: Catrachia (Coleoptera: Scarabaeidae)
}

\author{
María Milagro Coca-Abia ${ }^{1} \&$ Paul S. Robbins ${ }^{2}$ \\ 1 Centro de Investigaciones y Tecnologías Agroalimentarias (CITA). Unidad de Protección Vegetal. Crtra. de Montañana \\ a Peñaflor, 930. 50059 Zaragoza (Spain); mcoca@aragon.es \\ 2 Department of Entomology. New York State Agricultural Experiment Station. Cornell University. Geneva, NY 14456 \\ USA; psr1@cornell.edu
}

Received 02-III-2005. C Corrected 29-VI-2005. Accepted 07-XII-2005.

\begin{abstract}
A new genus and two species of Melolonthinae from Honduras and Nicaragua are described. A phylogenetic analysis, carried out using morphological characters, suggests that Catrachia is a strongly supported monophyletic group. Catrachia is therefore established as a new genus, constituted by two new species, Catrachia mariana and Catrachia nica. Rev. Biol. Trop. 54(1): 000-000. Epub 2006 Mar 31.
\end{abstract}

Key words: Catrachia, C. mariana, C. nica, taxonomy, phylogeny.

The Melolonthinae is a diverse scarab subfamily with a worldwide distribution. The taxonomy of this group is not well understood, despite the efforts of numerous workers in both the $19^{\text {th }}$ (Say 1825, Harris 1827, Bates 1888 ) and $20^{\text {th }}$ century (Luginbill and Painter 1953, Vaurie 1958, Báguena-Corella 1967, Frey 1975, Baraud 1977, Britton 1978, Moron 1986, Woodruff and Beck 1989, Baraud 1992, CocaAbia et al. 1993, Coca-Abia and Martín-Piera 1998, Coca-Abia 2000, Evans 2003 etc.).

Phyllophaga Harris 1827 is a New World melolonthine genus with $>800$ species presently assigned to ten sub-genera (Evans 2003, Smith and Evans 2005). Among the genera found in the New World Rhizotrogini, Phyllophaga is the genus that has the largest number of species and the greatest morphological diversity. It has long been evident that the systematics of the Phyllophaga present many problems, not the least being the number of species assigned in this genus without the employment of systematic criteria. Therefore, the large number of species, the degree of morphological diversity and the lack of use of systematic criteria to assign taxonomic status calls the monophyly of Phyllophaga into question. Coca-Abia (2002) demonstrated the polyphyly of Phyllophaga when the genus Trichesthes Erichson 1847 (synonymized with Phyllophaga by LeConte (1856)) was re-established.

The aim of this work is to contribute to a better understanding of the biodiversity of the Melolonthinae in the Neotropical Region. A new genus and two species from Honduras and Nicaragua are described and established with phylogenetic support.

\section{MATERIALS AND METHODS}

Both new species were captured in vane traps baited with rubber septa containing 4 mg each of various blends of the methyl esters of L-valine and L-isoleucine, sex pheromone compounds identified from a common North American species of Phyllophaga, P. anxia (LeConte 1850) (Zhang et al. 1997). Stated blends are in the ratio of the methyl esters of Lvaline/L-isoleucine. In 1996, when Catrachia 
mariana was captured, traps were baited with blends in the ratios of $100 / 0,65 / 35,50 / 50$, 35/65, and 0/100. In 2000, when C. nica was captured, traps were baited with blends in the ratios of $100 / 0,90 / 10,80 / 20,60 / 40,40 / 60$, 20/80, 10/90, and 0/100.

The phylogenetic analysis was based on external morphology, mouthparts and genitalic characters.

The mouthparts and genitalia (male and female) were removed and cleared in a hot solution of $5 \% \mathrm{KOH}$. After clearing, they were studied under immersion in distilled water. Additionally, the female genitalia were dehydrated in a progressive ethanol series $(70 \%$, 90\%, 95\% and 100\%) and mounted in Euparal.

Phylogenetic analysis was carried out using PAUP 4 (Swofford 2003). A heuristic search was used to find the most parsimonious trees. Support for the clades in the tree was assessed with bootstrapping (Felsenstein 1985).

Diplotaxis tristis Kirby 1837 was selected as the outgroup because the genus Diplotaxis is a sister group of the Phyllophaga.

The genera Trichesthes and Phyllophaga are represented by the type species $T$. tristis (F. 1781) and P. hirticula (Knoch 1801). In addition, representative species belonging to other subgenera in the Phyllophaga were selected to reflect the variation within the genus (Table 1).

The data set comprises 26 characters scored across 23 taxa. The characters include 16 from the external morphology (including mouthparts) and 10 from the genitalia (6 male, 4 female). Characters were polarised using the outgroup method as described by Nixon and Carpenter (1993). The multistate characters were treated as non-additive (Fitch 1971). In unordered multistate characters, the distance between all pairs of states was treated as a single step. The character state matrix used in the phylogenetic analysis may be seen in Table 1 .

1. Clypeus shape.

(0) Semi-circular; (1) bi-lobed;

(2) rectangular.
TABLE 1

Character matrix used in the phylogenetic analysis (Characters are described in the text). Explanation of symbols:

$0,1,2,3,4$ = character states; - missing characters

[ 10 20 ]

[.. ]

Diplotaxis tristis

Phyllophaga hirticula

Phyllophaga rorulenta

Phytalus prolixa

Phyllophaga chiriquina

Phyllophaga schizorhina

Chlaenobia latipes

Chlaenobia aequata

Chlaenobia tumulosa

Chirodines zunilensis

Listrochelus huachuca

Cnemarachis aeruginosa

Trichesthes tristis

Trichesthes gigantea

Trichesthes lissopyge

Trichesthes setifera

Phyllophaga tenuipilis

Phyllophaga cometes

Triodonyx gigantissima

Phytalus bilobatata

Phytalus obsoleta

Catrachia mariana

Catrachia nica

00000000000000000000000000 11011110021101001110001112 11011110021101001111001112 11011110-01-0000111100 - . . . $1101111012110100111100 \ldots$ 11011110-2000110111000 - . . . 01011201100110201210010111 01011201100110201210010111 01011201100110201210010111 01010201-00-0001141001 - - $01010-10100003001410011102$ 11011101010001101411010112 21010000000001111411101003 21010000-00-0111141110 - . . 21010000-20-0111141110- . $210100000-0001111411101003$ 21010000020001211411101003 21010000-00-0001141110 - . . . 21010-100100020000000000100 110100100000000001110011002 $110100000-0000001110001003$ 22100010020000001311000000 22100010-20-0000131000 - . . .

The semi-circular state is characterized in having the clypeus shaped like a semi-circle, i.e., oblique sides and a non-sinuated fore edge. The bi-lobed state is similar to the preceding state, with the exception of the fore edge, which is strongly sinuated medially. The rectangular state has parallel sides and a straight fore edge.

2. Clypeal lateral sides.

(0) Fused to the eye edge; (1) above the eye edge and slightly elevated; (2) above the eye edge and strongly elevated.

3. Frontal carina.

(0) Absent; (1) present.

4. Labrum.

(0) Narrow and wavy; (1) wide and depressed in the middle.

5. Incisor mandibular lobe.

(0) Smooth; (1) with a small notch. 
6. Molar mandibular lobe.

(0) Widely striate; (1) narrowly striate with holes; (2) narrowly striate without holes.

7. Maxillary galea.

(0) With strong tooth on the dorsal face;

(1) smooth or with weak tooth on the dorsal face.

8. Sensory area of the maxillary palpi.

(0) Round; (1) oval.

9. Female pygidium.

(0) Flat; (1) protruding.

10. Dorsal surfice of the metatibiae.

(0) Smooth; (1) with spurs; (2) with an edge.

11. Lower spur of metatibial plate.

(0) Articulated to tibiae; (1) fused to tibiae.

12. Female metatibial plate.

(0) Glabrous; (1) pubescent.

13. Brush of small setae on the inner surface of tarsal joints.

(0) Absent; (1) present.

14. Claw shape.

(0) Cleft; (1) simple with a basal tooth; (2) simple with two basal teeth; (3) serrated.

15. Abdominal sternites.

(0) Smooth; (1) with ornaments; (2) with setae.

16. Anal plate.

(0) Flat; (1) depressed.

17. Parameres/phallobase ratio.

(0) Greater than or equal to 1 (parameres longer than or equal to the phallobase);

(1) less than 1 (parameres shorter than the phallobase).

18. Arrangement of temones.

(0) Simple, with dorsal isolated plate;

(1) simple, symmetric, dorsally fused and without dorsal plate; (2) simple, asymmetric, dorsally fused and without dorsal plate; (3) simple with isolated dorsal structures; (4) median lobe.

19. Dorsal structures attached to temones.

(0) Present; (1) absent.

20. Setae of the endophallus.

(0) Inconspicuous; (1) conspicuous.

21. Shape of the endophallum.

(0) Sack-shaped; (1) flagello-shaped.

22. Ventral surface of the phallobase.

(0) Membranous; (1) sclerotized.
23. Median oviduct.

(0) Small and without sclerotized structures; (1) Well developed and with sclerotized structures or thick integument.

24. Genital chamber folding.

(0) Slight; (1) marked.

25. Genital chamber dorsal wall.

(0) Non-sclerotized; (1) with sclerotized structures.

26. Sensorial structures in the genital chamber.

(0) Sternites with setae at caudal position;

(1) isolated palpi; (2) dorsal plates; (3) hook plates (Coca-Abia 2002).

Genus Catrachia Coca-Abia and Robbins (NEW GENUS)

Type species: Catrachia mariana CocaAbia and Robbins (new species)

Diagnosis of the genus: Members of Catrachia can be characterized by the following features.

Head: Antenna with 9 segments; antennal club with three segments and shorter than the stem; mandible with edge of the incisor lobe straight (Figs. 1 and 3); moderately wrinkled molar lobe (Fig. 2); galea of the maxilla with very poorly developed teeth (Figs. 4 and 5); labrum gently depressed in the middle (Fig. 6 and 7) with very little pubescence; clypeus shorter than frons, clypeus abruptly widens from base and then quickly narrows; lateral sides arcuate and elevated in relation to the eye edge, anterior margin not sinuate at the middle; head coarsely and closely punctated and with conspicuous, with not very abundant pubescence; frontal carina highly developed; depressed vertex with punctures more densely distributed than on the frons; small and flat ocular carina; small eyes hidden by the anterior angle of the pronotum.

Prothorax: In dorsal view, glabrous pronotal surface with scattered punctures; anterior angles of the pronotum very sharp and prolonged towards the eyes; anterior margin of the pronotum thick, elevated and with a row of pubescence; posterior angles obtuse with rounded apex; softly serrated lateral margins, with scarce and short pubescence. 

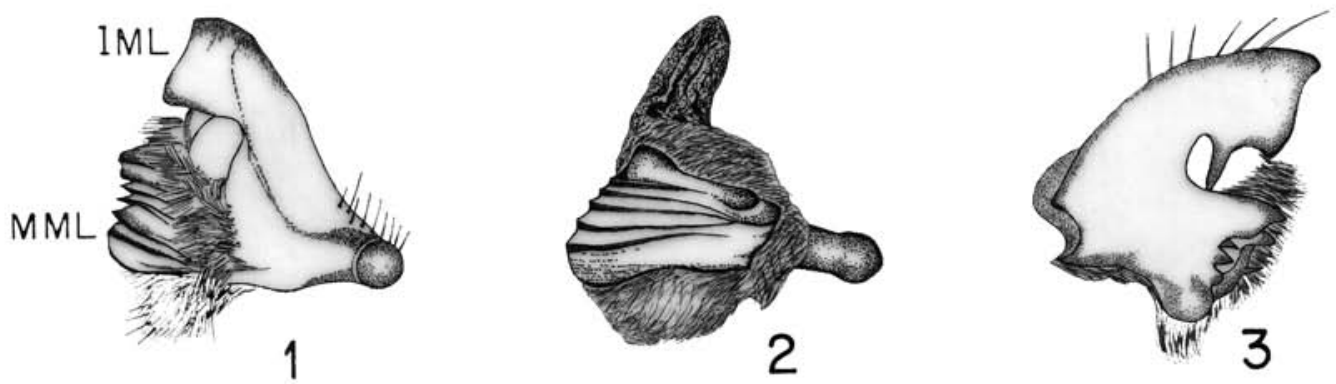

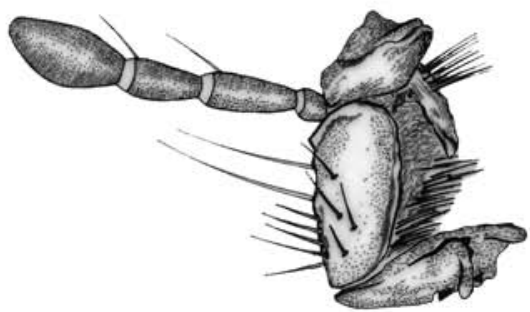

4

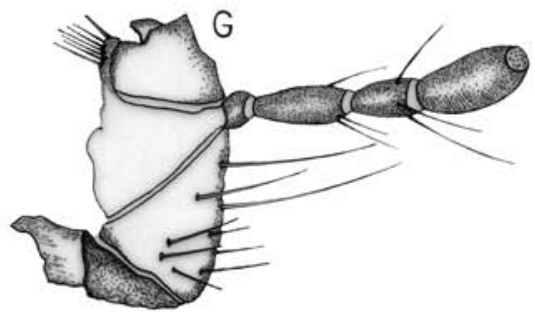

5
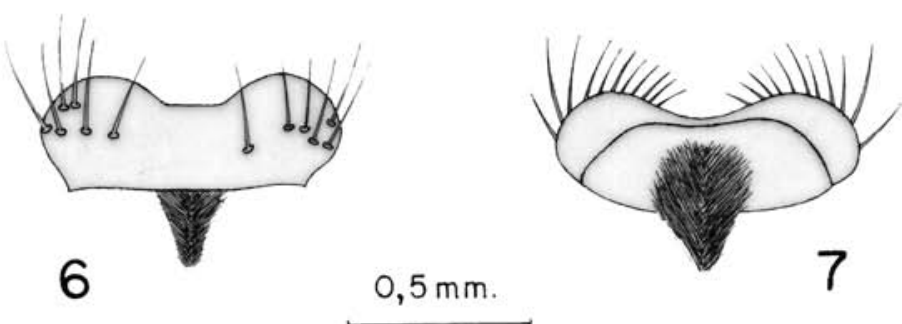

Figs. 1 to 7. Mouth parts of Catrachia mariana. Left mandible in ventral (1), lateral (2) and dorsal (3) views. Left maxilla in dorsal (4) and ventral (5) views. Labrum in dorsal (6) and ventral (7) views. G: galea. IML: incisor mandibular lobe. MML: molar mandibular lobe. 
Elytra: Glabrous elytral surface with shallow punctures; smooth, not striated.

Legs: Fore tibia with three teeth; meso and meta tibia with developed lateral carina. Cleft tarsal claws.

Pygidium: Strongly punctated with pubescent apex.

Abdominal sternites: Anal plate narrow. Abdominal sternites without ornament and moderately pubescent.
Male genitalia (Fig. 8): With parameres short (1/3 phallobase, approximately), ventrally separated. Endophallus long and thin (but not flagello-shaped); joined to the parameres by simple temones having two dorsal structures of differing shape and size. Epithelium of the endophallus covered with scattered sensillae. Genital segment with reduced vestigial sternite.

Etymology: General Florencio Xatruch led the defense of Honduras in 1857 against an

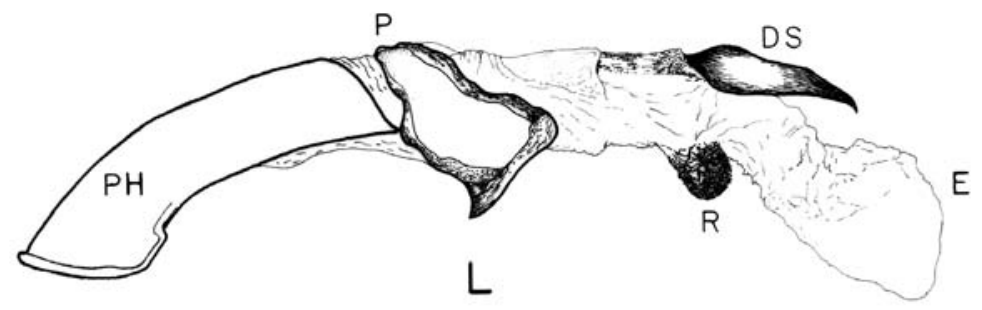

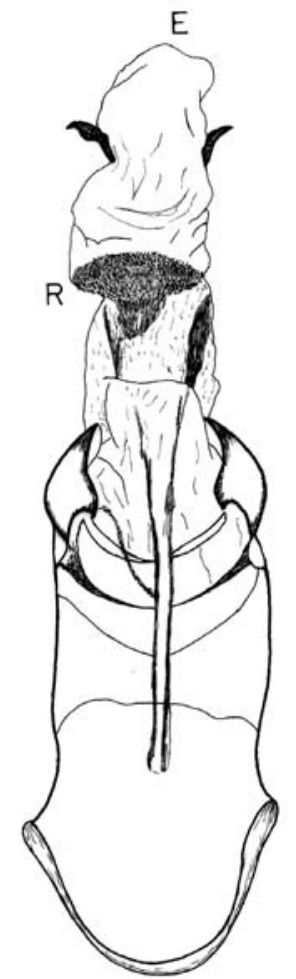

$\mathrm{V}$

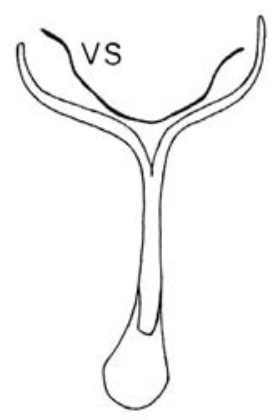

GS

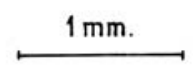

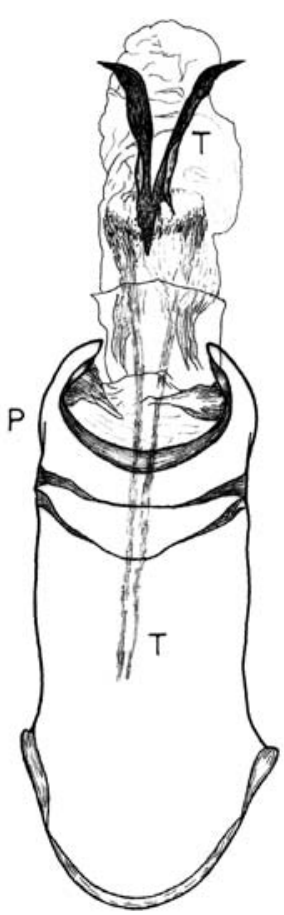

D

Fig. 8. Male genitalia of Catrachia mariana in lateral (L); ventral (V) and dorsal (D) views. E: endophallus; GS: genital segment; P: parameres; PH: phallobase; R: raspulae; T: temones; DS: dorsal structures of the temones. VS: vestigial sternite. 
attempted invasion by North American William Walker. The complimentary nicknames "catracho" or "catracha” (derived from Xatruch) refer to people of Honduran descent. This genus is named to honour the people of Honduras who endeavour to preserve the biodiversity of Central America for the benefit of all.

\section{Catrachia mariana Coca-Abia and Robbins \\ (NEW SPECIES)}

Types: Holotype: A male specimen in the collection of the Museo Nacional de Ciencias Naturales, Madrid (Spain) (MNCN), is the designated Holotype, labelled as: 1) white and printed label: Honduras, VI 1996, pheromone trap 100/0 valine/isoleucine; 2) red and printed

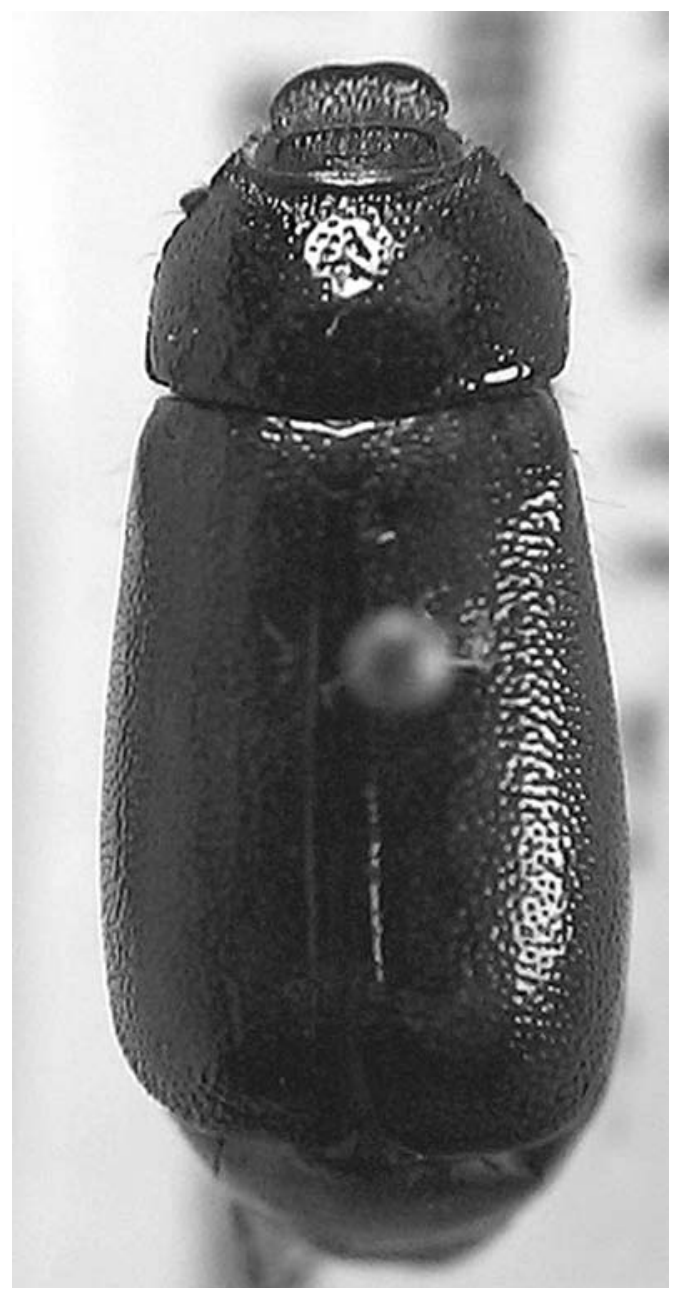

label: Holotype, Catrachia mariana Coca-Abia and Robbins, 2005.

Paratypes: A male and four female specimens in the collection MNCN are designated Paratypes, labelled as: 1) white and printed labels: Honduras VI 1996, pheromone trap 100/0 valine/isoleucine; 2) red and printed label: Paratype, Catrachia mariana Coca-Abia and Robbins, 2005.

Other specimens of $C$. mariana were deposited in the following collections: Cornell University, Ithaca, NY, USA; Florida State Collection of Arthropods, Gainesville, Florida, USA; Escuela Agrícola Panamericana de Zamorano, Apartado Postal No. 93, Tegucigalpa, Honduras; University

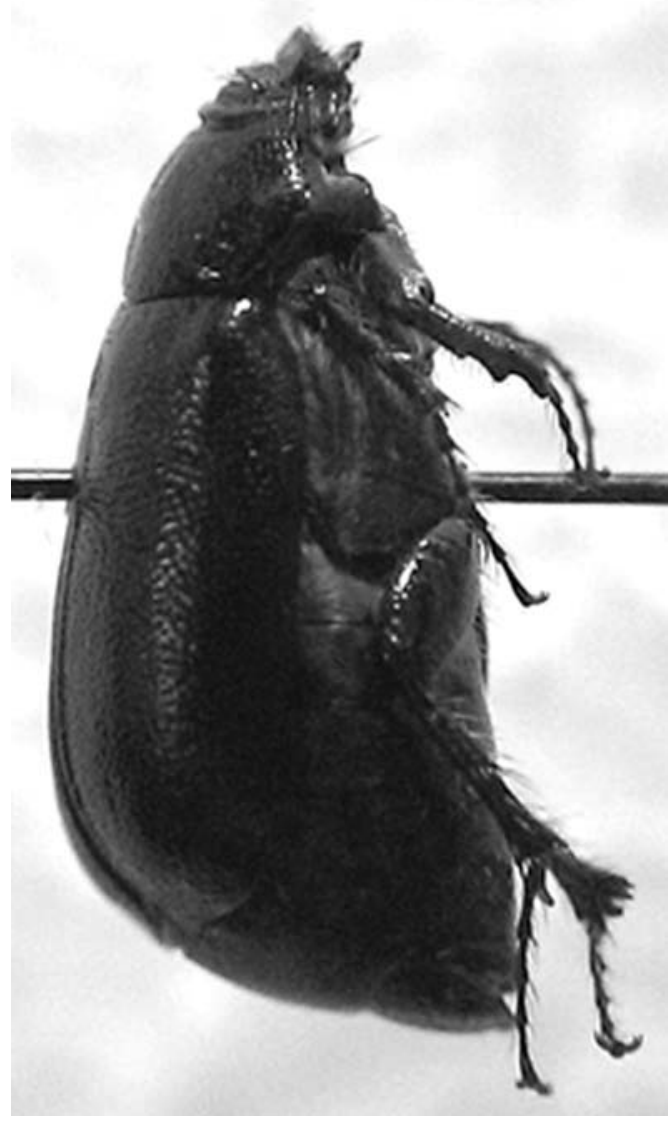

Figs. 9-10. Habitus of Catrachia mariana: in dorsal (9) and lateral (10) views. 
of Nebraska State Museum, Systematics Research Collections, Lincoln, Nebraska, USA, and the personal collection of the junior author (PSR).

Description: Habitus as in Figures 9 and 10. In addition to the generic features, this species can be characterized by: antennal clubs about the same size in both sexes. Pronotal surface with wide and deep punctures; punctures more densely distributed on the anterior edge than on the remaining part of the pronotum. Pygidium with wide and deep punctures of indistinct outline and inconspicuous pubescence on the surface. Dorsal surface of the metatibia with an edge.

Male genitalia (Fig. 8) with highly developed and spear-like, dorsal structures of the temones which are recumbent when the endophallum is at rest, and raised when the endophallum is projected. Endophallum with a raspullae in the ventral position.

Female genitalia very little sclerotized. Large, deep genital chamber with the distal edge sclerotized, thick integument, well developed sternites, dorsal genital palpi and two thin and long tergites. Median oviduct without sclerotized structures and with membranous integument. Pedunculated bursa copulatrix with a proximal duct (ductus bursae) and a slightly dilated distal blister (corpus bursae). Spermatheca inserted directly on the median oviduct and twice as short as its gland. Two accessory glands.

Material examined: All specimens of the type series were trapped in Zamorano, Honduras between May 27 and June 6, 1996 in a sex attractant trap.

Etymology: This species is named to honor Maryann Robbins, wife of the junior author, whose enthusiasm for, and willingness to participate in numerous beetle adventures has made the life work of the junior author pleasant indeed.

\section{Catrachia nica Coca-Abia and Robbins} (NEW SPECIES)

Type: A male specimen in the MNCN collection is designated Holotype, labelled as: 1) white and handwritten label: J. Collins, Estelí Nicaragua, 5/28/00; 2) white and printed label: pheromone trap 90/10 valine/isoleucine; 3) red and printed label: Holotype, Catrachia nica Coca-Abia and Robbins, 2005. Females unknown.

Description: Habitus as in Figure 11. In addition to the generic features, this species can be characterized by: pronotal surface with homogeneously distributed thin and shallow punctures. Pygidium with thin, deep and outlined punctures; conspicuous surface pubescence. Dorsal surface of the metatibia scarcely dentate and with an edge.

Male genitalia with the dorsal structures of the temones relatively undeveloped and drumstick shaped. Endophallum without raspullae in ventral position

Material examined: type specimen trapped in Estelí, Nicaragua, 5/28/00 in a sex attractant trap.

Etymology: This species is named in honor the people of Nicaragua who endeavor to preserve the biodiversity of Central America for benefit of all.

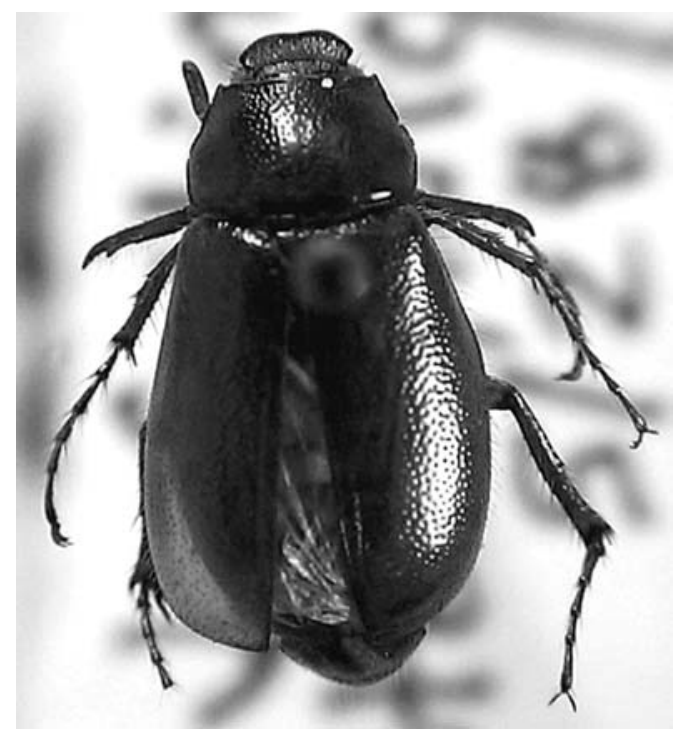

Fig. 11. Habitus of Catrachia nica in dorsal view. 


\section{Phylogenetic analysis}

A maximum parsimony analysis (heuristic search) using equal weights yielded 18 equally parsimonious cladograms, each with 67 steps. The consistency (CI) and retention (RI) indices were 0.567 and 0.803 , respectively. All consensus trees

12

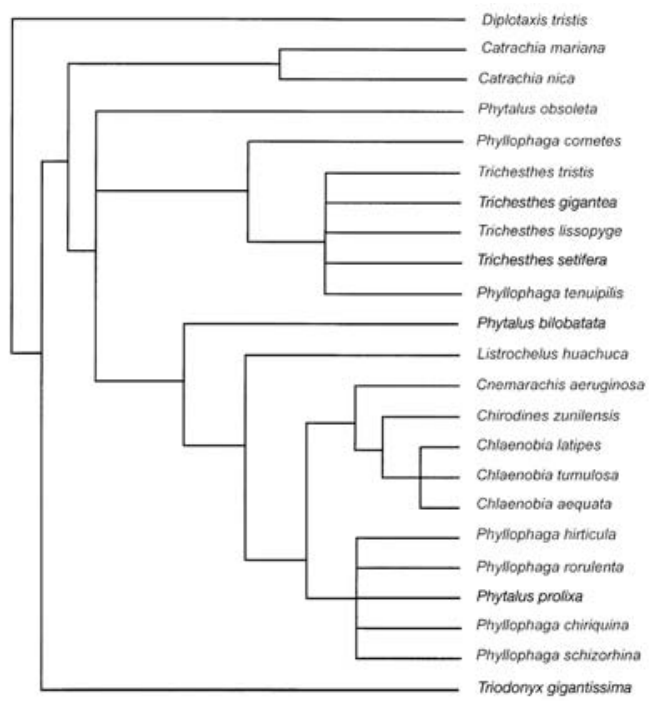

14

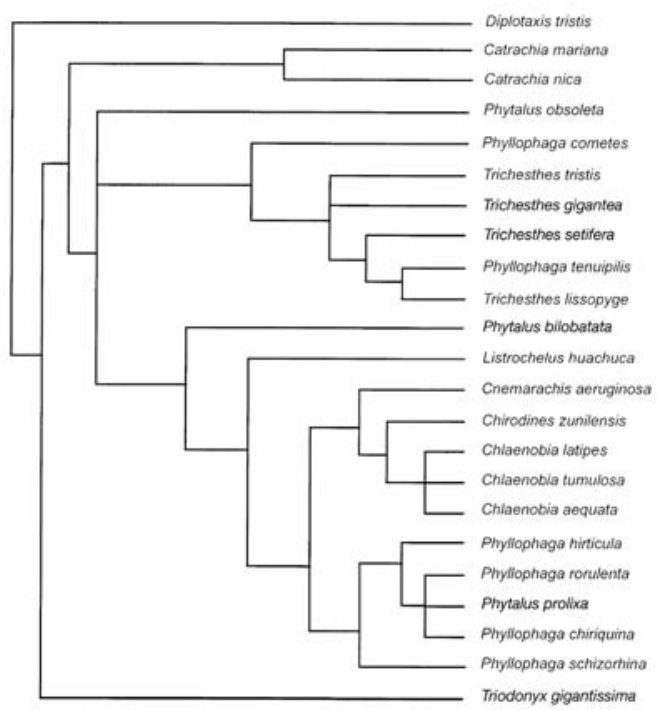

displayed the same topology except in the terminal taxa Phyllophaga and Trichesthes (Figs. 12-15).

The results of character weighting were stable in three successive iterations, yielding 6 trees of length 314 steps, a CI of 0.732 and an RI of 0.887 All weighted consensus trees displayed the same topology (Fig. 16).

13

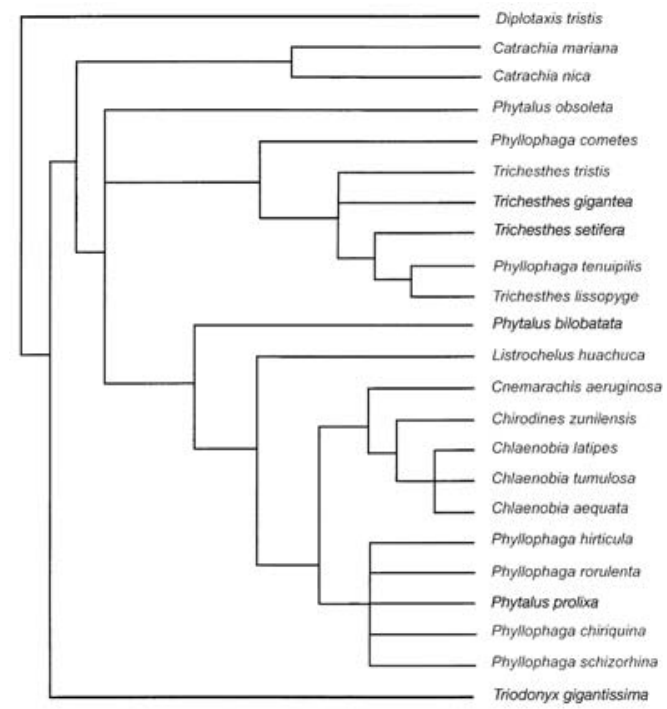

15

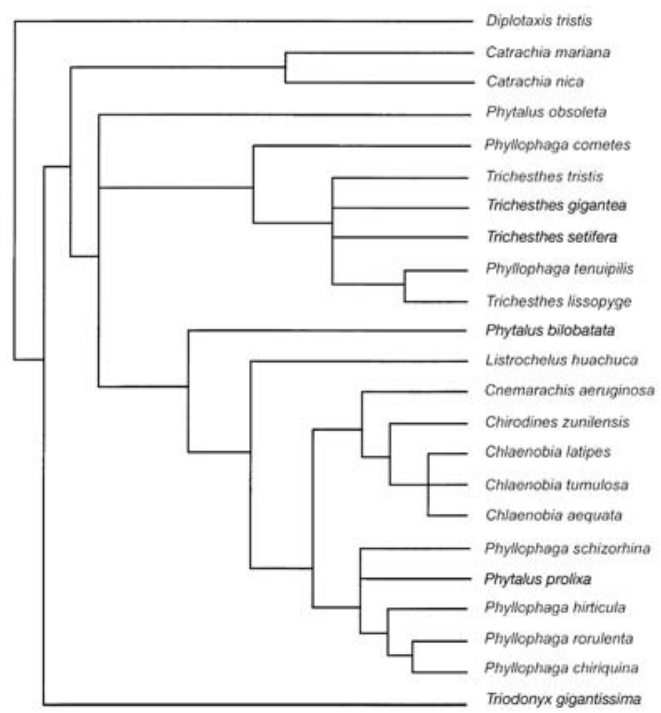

Figs. 12-15. Strict (12), Semistrict (13), 50\% Majority-rule (14) and Adams (15) consensus trees of 18 unweighted cladograms. $\mathrm{L}=67$ steps; $\mathrm{CI}=0.567 ; \mathrm{RI}=0.803$. 


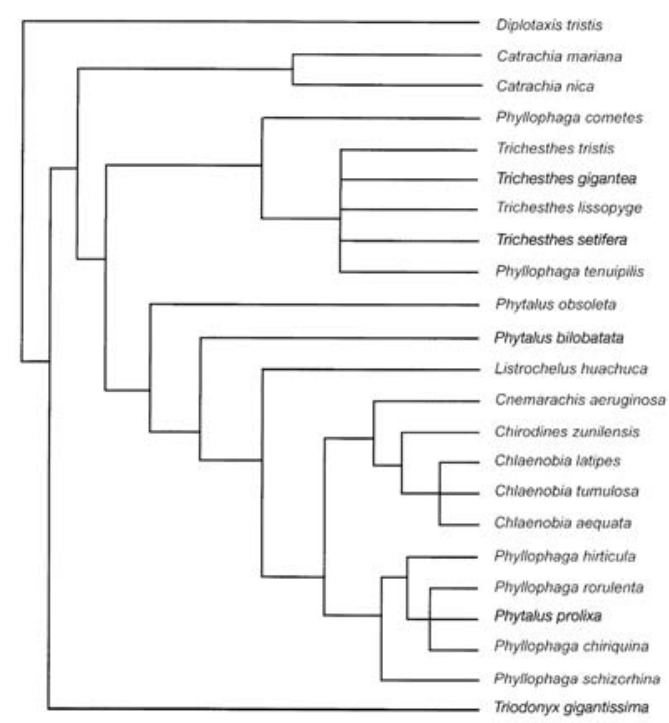

Fig. 16. Strict consensus tree of 6 weighted cladograms. $\mathrm{L}=314$ steps; $\mathrm{CI}=0.732 ; \mathrm{RI}=0.887$.

The bootstrapping analysis (Fig. 17) provided considerable support for the basal clade (87\% bootstrap). Triodonyx gigantissima occupies a basal position outside the main clade. Two clades emerge above the $T$. gigantissima

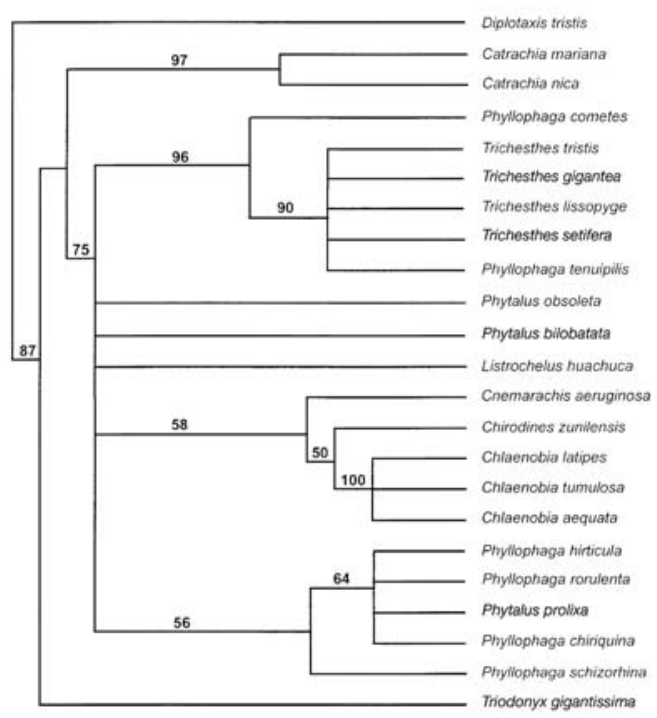

Fig. 17. Bootstrap 50\% Majority-rule consensus tree. Numbers on the branches indicate the robustness of support (\%). node, one comprised of Catrachia mariana and Catrachia nica, and the other composed of species from Phyllophaga, Chlaenobia, Chirodines, Cnemarachis, Listrochelus, Phytalus and Trichesthes .

The bootstrap analysis provides considerable support for the clade established by the two species included in the new genus Catrachia (97\% bootstrap) (Fig. 17). This clade is supported by unambiguous synapomorphic characters $(\mathrm{CI}=1$ and $\mathrm{RI}=1)$ such as the lateral edges of the clypeus strongly elevated over the eyes (character 2) and a well developed frontal carina (character 3). The second major clade also has considerable support (75\% bootstrap) but there is, however, a basal conflict that leaves unresolved the relationships of the taxa in question.

\section{DISCUSSION}

Catrachia constitutes a monophyletic group that is well supported (Fig. 17) by autapomorphic characters which clearly distinguish it from Phyllophaga, Chlaenobia Blanchard 1850, Chirodines Bates 1888, Cnemarachis Saylor 1942, Listrochelus Blanchard 1850, Phytalus Erichson 1847 and Trichesthes Erichson 1847. These allied genera and subgenera form a monophyletic group, but this analysis does not resolve their phylogenetic relationships. The cladogram does, however, provide clear evidence that Catrachia and its allied genera and subgenera are sister clades (Fig. 17).

Morphological and genitalic features which distinguish Catrachia from allied genera and subgenera (lateral sides of clypeus strongly elevated over the eyes, strong frontal carina and temones with two dorsal structures), together with its phylogenetic position as sister group of the genus Phyllophaga, allow us to establish Catrachia as a group with the same taxonomic rank as the genus Phyllophaga. Therefore, the genus Catrachia is hereby established with two species: Catrachia mariana and Catrachia nica. 


\section{ACKNOWLEDGMENTS}

We thank Emilio Soteras Polo for the illustrations and Museo Nacional de Ciencias Naturales of Madrid for use of the facilities to produce them. We also thank Dr. Michael Zeiss and Harold Argüello of Escuela Agrícola Panamericana de Zamorano, Tegucigalpa, Honduras and Ms. Jodi Collins of Cornell University, Ithaca, NY, USA, for maintaining the trap lines in which the insects were captured.

\section{RESUMEN}

En este trabajo se describe el género Catrachia y dos especies nuevas, Catrachia mariana y Catrachia nica de Honduras y Nicaragua respectivamente. En análisis filogenético basado en caracteres morfológicos demostró que Catrachia es un grupo monofilético fuertemente soportado lo cual permite su consideración como género nuevo.

Palabras clave: Catrachia, C. mariana, C. nica, taxonomia, filogenia.

\section{REFERENCES}

Báguena-Corella, L. 1967. Scarabaeoidea de la Fauna Ibero-Balear y Pirenaica. Instituto Español de Entomología (Consejo Superior de Investigaciones Científicas). 561 p.

Baraud, J. 1977. Coléoptères Scarabaeoidea. Fauna de l'Europe occidentale. Belgique, France, Grande Bretagne, Italia, Peninsule Ibérique. Nouv. Rev. Entom. 7: 1-532.

Baraud, J. 1992. Faune de France, 78. Coléoptères Scarabaeoidea d'Europe. Federation française des Sociétés de Sciences Naturelles et société Linnénne de Lyon. 856 p.

Bates, H.W. 1888. Biologia Centrali-Americana. Insecta Coleoptera 2: 161-416.

Blanchard, C.E. 1850. Catalogue de la collection entomologique. Classe des Insectes. Ordre des Coléoptères. In H. Milne-Edwards, E. Blanchard \& H. Lucas (eds.) Museum d'Histoire Naturelle, Paris, France.

Britton, E.B. 1978. A revision of the Australian chafers (Coleoptera: Scarabaeidae: Melolonthinae). Tribe Melolonthini. Aust. J. Zool., Suppl. Ser. 60: 1-150.
Coca-Abia, M. 2000. Polylamina Hardy, a junior synonym of Polyphylla Harris (Coleoptera, Scarabaeidae, Melolonthinae, Melolonthini). Coleop. Bull. 54: 1122.

Coca-Abia, M. 2002. Reestablishment of the genus Trichesthes Erichson, 1847 (Coleoptera: Scarabaeidae: Melolonthinae) based on phylogeny. J. Entomol. Soc. New York 110: 95-114.

Coca-Abia, M \& F. Martín-Piera. 1998. Revisión taxonómica del género Rhizotrogus Berthold, 1827 (Coleoptera: Scarabaeidae, Melolonthinae). Coleopterological Monographs 2: $140 \mathrm{p}$.

Coca-Abia, M., F. Martín-Piera, \& M.A. Morón. 1993. Anatomía y morfología de la genitalia feminina de las especies mexicanas del género Phyllophaga (sensu lato) (Coleoptera, Melolonthidae). Relaciones filogenéticas con otros géneros del área mediterránea. G. It. Ent. 6: 263-274.

Erichson,W.F. 1847. Naturgeschinchte der insecten Deutschlands. Coleoptera. NicolaischeBuchhandlung, Berlin, Germany, p. 656-662.

Evans, A. 2003. A checklist of the New World chafers (Coleoptera: Scarabaeidae: Melolonthinae). Zootaxa. 211:1-419.

Fabricius, J.C. 1781. Species Insectorum exhibentes eorum differntias specificas, synonyma, auctorum, loca natalia, metamorphosin adiectis observationibus, descriptionibus. Vol. 1 Proft. Hafniae. 348 p.

Felsenstein, J. 1985. Confidence limits on phylogenies: an approach using the bootstrap. Evolution. 38: 16-24.

Fitch, W.H. 1971. Towards defining the course of evolution: Minimal change for a specific tree topology. Syst. Zool. 20: 406-416.

Frey, Von G. 1975. Bestimmungstabelle der Südamerikanischen Arten der Gattung Phyllophaga Harris und ihrer Untergattung Phytalus Er. (Col. Melolonthidae). Ent. Arb. Mus. Frey. 26: 201-226.

Harris, T. W. 1827. Minutes toward a history of some American species of Melolonthinae particularly injurious to vegetation. Mass. Agr. J. 10: 1-12.

Kirby, W. 1837. In J. Richardson (ed.). Fauna BorealiAmericana. Insects. Coleoptera. Part 4. Norwich, London. 249 p.

Knoch, A.W. 1801. Neue Beiträge zur Insectenkunde. Theil 1.Schwickertschen Verlage, Leipzig. 208 p.

LeConte, J.L. 1856. Synopsis of the Melolonthidae of the United States. J. Acad. Nat. Sci. Phila. 3: 225-288. 
Luginbill, P. \& Painter, H.R. 1953. May beetles of the United States and Canada. U.S. Dep. Agric. Tech. Bull. 1060. 102 p.

Morón, M.A. 1986. El género Phyllophaga en México. Morfología, distribución y sistemática supraespecifica (Insecta: Coleóptera). Publicaciones Instituto de Ecología, No.19. 341 p.

Nixon, K.C. \& Carpenter, J.M. 1993. On outgroups. Cladistics. 14: 221-228.

Ratcliffe, B.C. 1991. The scarab beetles of Nebraska. Bull. Univ. Nebr. State Mus. 12: 158-226.

Say, T. 1825. Descriptions of new species of Coleopterous insects inhabiting the United States. J. Acad. Nat. Sci. Phila. 5: 160-204.

Saylor, L.W. 1942. Ten new Phyllophaga beetles from Panama and South America. Rev. Entomol (Rio de Janeiro). 13: 154-166.

Smith, A. B. T. \& Evans, A. V. 2005. A supplement to the checklist of the New World chafers (Coleoptera:
Scarabaeidae: Melolonthinae) with notes on their tribal classification. Zootaxa. 1032: 29-60.

Swofford, D.L. 2003. PAUP*: Phylogenetic Analysis Using Parsimony (*and Other Methods), version 4. Sinauer Associates, Sunderland, Massachusetts, USA.

Vaurie, P. 1958. A revision of the genus Diplotaxis (Coleoptera, Scarabaeidae, Melolonthinae). Part 1. Bull. Am. Mus. Nat. Hist. 115: 269-396.

Woodruff, R.E. \& Beck, B.M. 1989. The scarab beetles of Florida (Coleoptera: Scarabaeidae) Part II. The May or June Beetles (genus Phyllophaga). Arthropods of Florida and Neighboring Land Areas. Florida Department of Agriculture and Consumer Services. Division of Plant Industry. Gainesville, Florida, USA. 223 p.

Zhang, A., P.S. Robbins, W.S. Leal, C.E. Linn Jr., M.G. Villani \& W.L. Roelofs. 1997. Essential amino acid methyl esters: major sex pheromone components of the cranberry white grub, Phyllophaga anxia (Coleoptera: Scarabaeidae). J. Chem. Ecol. 23: 231-245. 
